\title{
Why does renewable energy diffuse so slowly? A review of innovation system problems
}

\author{
Simona O. Negro*, Floortje Alkemade, Marko P. Hekkert \\ Innovation Studies, Copernicus Institute of Sustainable Development and Innovation, Utrecht University, Heidelberglaan 2, 3584 CS Utrecht, The Netherlands
}

\section{A R T I C L E I N F O}

\section{Article history:}

Received 10 October 2011

Accepted 13 March 2012

Available online 30 April 2012

\section{Keywords:}

Renewable energy technologies

Innovation system failures

Policy

R\&D

\begin{abstract}
A B S T R A C T
In this paper we present a literature review of studies that have analysed the troublesome trajectory of different renewable energy technologies (RETs) development and diffusion in different, mainly European countries. We present an overview of typical systemic problems in the development of innovation systems around RETs. We make use of the literature on innovation system failures to develop a categorisation of typical systemic problems that hamper the development and diffusion of RETs. Based on this categorisation the paper suggests several policy recommendations to overcome the systemic problems and accelerate the diffusion and implementation of RETs.
\end{abstract}

(c) 2012 Elsevier Ltd. All rights reserved.

\section{Contents}

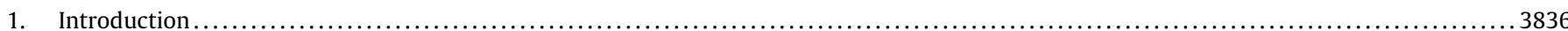

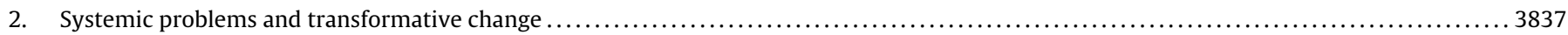

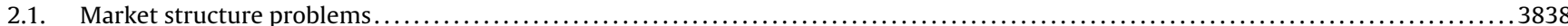

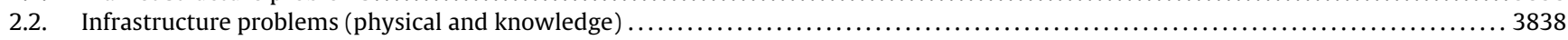

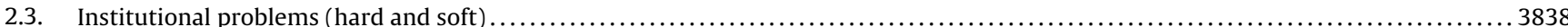

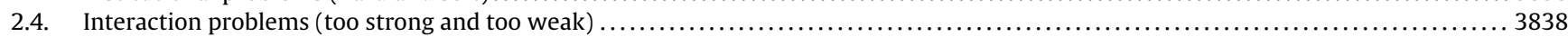

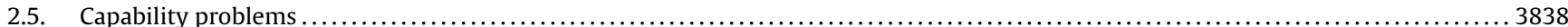

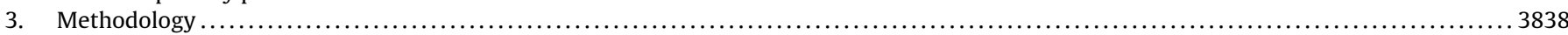

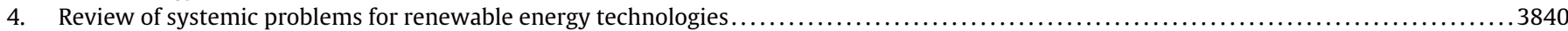

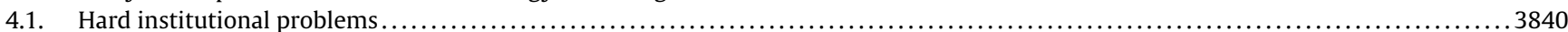

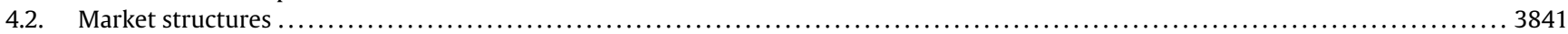

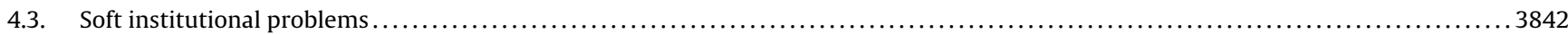

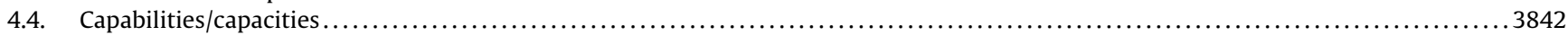

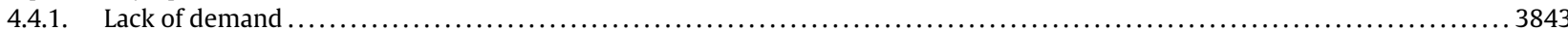

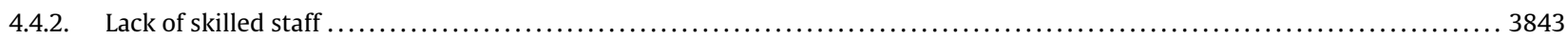

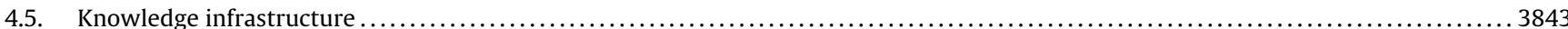

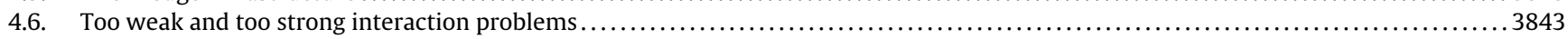

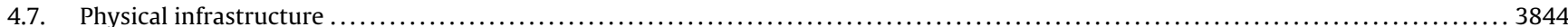

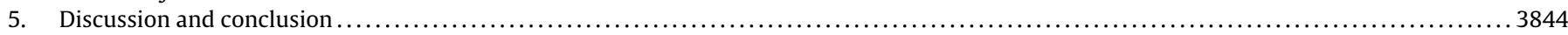

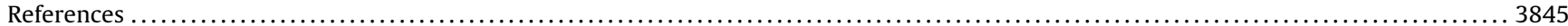

\section{Introduction}

Energy is literally the fuel for economic processes and growth. For this reason energy policy has always been an important part of economic and industrial policy. In the pre-Kyoto period, energy

\footnotetext{
* Corresponding author. Tel.: +31 30 2537166; fax: +31 302532746.

E-mail address: S.O.Negro@uu.nl (S.O. Negro).
}

policy mainly aimed at realising an affordable, reliable and secure energy system in order to maximally facilitate energy intensive industrial processes. In 1997 the Kyoto protocol was adopted. In this protocol 37 Annex I countries ${ }^{1}$ committed themselves to the reduction of greenhouse gases. As a consequence climate change 
and greenhouse gas emission reduction became important pillars in contemporary energy policies during the post-Kyoto period. In the same period geo-political instability like the war in Irak, the energy crisis during the 2000s and the natural gas dispute between Russia and Ukraine showed the international character of the energy system and the dependence on this system by individual countries. Renewable energy sources and technologies were identified as a means to reduce the impact of the energy system on the global climate and to reduce the dependence of national energy systems on foreign oil and gas. This realisation has led to a boost in renewable energy related research policies and industrial policies. The UK for example increased public R\&D expenditures related to renewables by a factor 10 during in the period 1997-2008 [1].

However, even though many years of public efforts and government money have been invested in order to speed up the development, diffusion and implementation of renewable energy technologies (RETs), experiences in different countries show that this is a very slow and tedious process [2-10]. For the OECD as a whole the share of renewables in the total energy supply increased from $6.2 \%$ in 1997 to $7.1 \%$ in 2008 . For the UK this share rose in the same period from $1 \%$ to $2.8 \%$ and for the US the share stayed roughly the same at a little over $5 \%$. The EU (27) did relatively well by increasing the share from $5.7 \%$ to $8.2 \%$ in the period $1994-2007$ [11]. However, these figures indicate that the actual share of RETs is still low, especially when compared to the ambitions of policy makers. The UK has set a renewable energy target of $15 \%$ for 2020 and the EU renewable energy target is $20 \%$ by 2020 . For the longer term the ambitions are even higher. The UK has a target to reduce carbon emissions by $80 \%$ in 2050 and during the Copenhagen summit Europe offered to cut emissions by $95 \%$ in 2050 . Both targets imply a large increase in the share of renewables. Realising such an increase requires insight in the factors that have hampered the speed of development and diffusion of renewables so far.

There are two different scientific paradigms to explain the slow diffusion of RETs. The first is the neo-classical economic paradigm that highlights market failures [12] as the main obstacle. Getting the prices right (by means of taxes and subsidies) and public R\&D subsidies to compensate for the private under investments in RETs $R \& D$ are the often proposed solutions, although the market failure approach was particularly weak in identifying where those subsidies should go, and what their level should be [13].

Another academic paradigm challenges this neoclassical view. These scholars highlight the systemic character of innovations. In their view, the speed, direction and success of innovation processes are strongly influenced by the environment in which innovations are developed. This environment is called innovation system, technological system or innovation ecosystem. Innovation systems are socio-technical configurations of actors, rules, physical infrastructures and their relations. These scholars highlight that besides market failures, many other system failures may exist that hamper the swift development and diffusion of innovations. In this article we analyse the reasons for the problematic diffusion of RETs using such an innovation systems perspective.

Scholars have sought explanations for this slow diffusion both in the nature and the characteristics of the incumbent systems and of the emerging alternative systems. The existing energy system hampers the diffusion of new energy technologies due to the inertia that is inherent in large technological systems such as the energy system and due to the strong interrelatedness between the energy system and the economic system [14]. Literally all economic processes depend on the current energy system. Therefore, transforming the energy system will affect all other parts of the economy and transforming it into a sustainable one will require an effort of change beyond anything that we have witnessed so far [15].
The relation between the existing energy system and emerging RETs is important for understanding the slow diffusion of these technologies. Some of the technologies that enable the transition to a more sustainable energy system substantially differ from the technologies that are in use today. The innovation literature labels these innovations as radical innovations [16], disruptive innovations [17] or system innovations [18]. The main difference between incremental innovations and radical innovations is that incremental innovations fit well in existing innovation systems while radical innovations do not. For the latter a new innovation system needs to build up. The literature agrees that the build-up of completely new innovation systems takes time. Van de Ven et al. [19] states it as follows "The time, costs and risk incurred by firms in developing an innovation are inversely related to the developmental progress of building an infrastructure for the new technology" [19]. In other words, more novel innovations require greater changes in all parts of the system and therefore greater development times, which increase the chance of failure.

The building up of new innovation systems is not a smooth and efficient process. Very often, specific difficulties arise that hamper the development of new innovation systems. In the literature these are labelled as 'system failures' [13,20-22], 'system imperfections' [23] or 'systemic problems' [24,25]. In the case of modern innovation policy, system failures are used as justification for policy intervention [26]. In the literature several categories of system failures have been identified [13,20-22,27]. In this paper we link these general theoretical categories of system failures (that we label as systemic problems) to the specific problems encountered in the diffusion of RETs. We first provide a classification of system failures as identified in the literature and then perform an extensive literature review of actual problems identified in RETs case studies (different technologies in different countries) assigning each problem to a systemic problem class. Linking the literature on systems failures with descriptive studies on RETs allows us to (1) gain insights in the specific problems of the energy system, and (2) get a systematic overview of problems which enables a better designed systemic policy approach [24]. The main research question of our paper is:

Which systemic problems hamper the development and diffusion of renewable energy technologies?

In Section 2 we will provide a literature overview of different typologies of systemic problems. Section 3 will explain the methodology used to categorise the empirical data to the systemic problems. In Section 4 we will provide a literature overview of 50 articles that studied the development process of different RETs in different countries (mostly European) and identified specific problems. We categorise the identified empirical problems using a theoretical typology of system failures. We finally end with conclusions and policy recommendations.

\section{Systemic problems and transformative change}

The notion of long-term transformative change captures the idea that fundamental changes in our systems of production and consumption are needed, i.e. novel configurations of actors, institutions and practices [27]. Governments often seek to stimulate or steer such transformations in order to reach societal goals and to bring about this transformative change. One of the approaches that legitimises intervention and provides a basis for designing research, technology and innovation (RTI) policy is the innovation systems approach [28-31].

Innovation systems analyses are especially useful for analysing which systemic problems hamper the development and diffusion of innovations. In fact, since the introduction of innovation systems approach (e.g. [32]) system failures or system problems are defined as the new rationale for government interventions [21]. System 
approaches are believed to have a greater potential for identifying where public support should go and to identify areas of systematically weak performance than the neoclassical perspective $[13,26]$. Various authors have provided listings of possible systemic failures and problems. However in order for these categories of system problems to lead to policy interventions a clear link between the empirically observed problems in a certain domain and the conceptual categories of system problems is needed.

The literature described systemic problems as 'systemic failure' [33], 'weakness', 'imperfection' or 'problems' [13,21]. Lipsey et al. [34] argue that when technology changes endogenously and in conditions of uncertainty there is no optimality nor equilibrium, and so optimum allocation of resources or optimal policies are not possible. In such conditions it is impossible to talk about a failure or an 'imperfection' [25]. A weakness is equally inappropriate term in that context as a weakness is not necessarily a problem; a situation that needs action [25]. This paper therefore refers to these systemic failures, weaknesses or imperfections as systemic problems. We thereby define systemic problems as "all systemic factors that block the operation and the development of innovation systems". Table 1 provides an overview of the categories of systemic problems identified in the literature (adapted from Wieczorek [25]).

As this paper has a review character we choose to use a comprehensive list of systemic problems for our survey including: market structure problems, infrastructural problems, institutional problems, interaction problems and capabilities problems. Following Klein Woolthuis et al. [21] we leave out lock-in problems as lockin is an outcome of other systemic problems. We will now briefly describe the categories of systemic problems.

\subsection{Market structure problems}

Market structure is defined as the organisation of the current market and the criteria used to select innovations. A new technology may suffer from competing incumbent substitutes that have been able to undergo a process of increasing returns [35]. This tends to associate the new product with a high price (lack of scale and experience economies) or low utility (poor performance, lack of network externalities and/or infrastructure). If the gap is very large, and if there is a paucity of nursing [36] or bridging segments [37] that allow for a gradual generation of increasing returns, a new technology may never have the chance to rectify these initial disadvantages. Also, the selection processes in the market may not involve a 'free' choice by customers when the market is controlled by dominant incumbents [20]. Also traditional market failures belong in this category.

\subsection{Infrastructure problems (physical and knowledge)}

Infrastructure is the basic physical and organisational structure needed for the operation of a society or enterprise or the services and facilities necessary for an economy to function. Knowledge infrastructure refers to both physical assets such as highly specialised buildings (laboratories and testing facilities) and equipment, as well as to non-physical assets related to scientific and applied knowledge. Physical infrastructures refer to the technical structures necessary for a society to function like electricity grids, natural gas grids, high-speed ICT infrastructure, and highway systems. Infrastructure problems are normally associated with the absence of necessary infrastructures for the new technological trajectory. Physical infrastructures usually play a large role in the transformation of large technical systems such as the energy system. Large investment costs and coordination problems associated with the build-up of a new infrastructure are a reason for government intervention in these transformation processes [21].

\subsection{Institutional problems (hard and soft)}

Institutions form a key factor in innovation systems theory that envisages the institutional context as a defining and structuring element in the system, and institutional problems refer to the institutional mechanisms that may hinder innovation. Hard institutions are formal, written, consciously created institutions, e.g. technical standards, labour law, risk management rules, etc. Soft institutions refer to informal, often evolved spontaneously and may be the implicit 'rules of the game', e.g. social norms and values, the legitimacy of new technology, culture, willingness to share resources with other actors, entrepreneurial spirit within organisations, industries, regions and countries and tendencies to trust, risk averseness. Taken together these institutions are conceptualised as the selection environment in which firms, knowledge institutes as well as the government itself are embedded [21].

\subsection{Interaction problems (too strong and too weak)}

Market relationships 'persist through time and involve interfirm cooperation in the development and design of products' $[13,21]$. Interactions not only involve relationships with other firms but also the interaction with, e.g. the government, public knowledge institutes, and third parties such as specialised consultants. Interaction problems can be caused by either too strong or too weak interactions. Strong interaction problems occur within a network when individual actors are guided in the wrong direction by network actors and consequently fail to supply each other with the required knowledge or when the network is too closed and actors become reluctant to exit the group or let new entrants in. Actors may also be 'locked into' their relationships due to asset specificity, switching costs or due to lack of alternative partners. Weak network failures occur when the connectivity among complementary technologies and actors is poor, fruitful cycles of learning, adaptation to new technological developments and innovation are therefore prevented. Moreover, if organisations in a system interact poorly this may lead to a lack of shared vision of future technology developments, which in turn might hinder the coordination of research efforts and investment [21].

\subsection{Capability problems}

Companies can simply lack the competences, capabilities or resources to make the leap from an old to a new technology or paradigm $[21,38,39]$. With regard to search processes firms build upon their existing knowledge base and other assets when they search for new opportunities, therefore they may be ignorant of opportunities which are at some distance: their vision may also be 'bounded' [20].

\section{Methodology}

In order to gain insight in the actual system problems that hamper the development and diffusion of RETs we analyse 50 case studies that analyse developments of RETs using a sociotechnical framework. The articles are selected from Scopus through keyword search using the following keywords: innovation systems; technological change; socio-technical; transition management; biomass; biofuels; biopower; CHP; hydrogen; green power; renewable energ*; photovoltaic; PV, marine; wind. Only those articles are selected that a socio-technical theory framework with insights from empirical case studies. The selection process resulted in about 50 papers that where included in the analysis (see Table 2 for an 
Table 1

\begin{tabular}{|c|c|c|c|c|c|c|c|c|}
\hline Systemic problems & OECD 1997 & Smith 2000 & $\begin{array}{l}\text { Jacobsson and } \\
\text { Johnson } 2000\end{array}$ & $\begin{array}{l}\text { Klein Woolthuis } \\
\text { et al. } 2005\end{array}$ & $\begin{array}{l}\text { Chaminade and } \\
\text { Edquist } 2007\end{array}$ & $\begin{array}{l}\text { Foxon and Pearson } \\
2007\end{array}$ & Mierlo et al. 2010 & $\begin{array}{l}\text { Weber and } \\
\text { Rohracher } 2011\end{array}$ \\
\hline Hard and soft institutions & $\begin{array}{l}\text { Mismatch between } \\
\text { basic and applied } \\
\text { research; } \\
\text { Malfunctioning of } \\
\text { the technology } \\
\text { transfer } \\
\text { institutions }\end{array}$ & $\begin{array}{l}\text { Institutional } \\
\text { failures }\end{array}$ & $\begin{array}{l}\text { Legislative failures; } \\
\text { Failures in } \\
\text { educational system }\end{array}$ & $\begin{array}{l}\text { Hard institutional } \\
\text { failures; } \\
\text { Soft institutional } \\
\text { failures }\end{array}$ & $\begin{array}{l}\text { Institutional } \\
\text { problems (hard); } \\
\text { Institutional } \\
\text { problems (soft) }\end{array}$ & & $\begin{array}{l}\text { Institutional } \\
\text { (hard); } \\
\text { Institutional (soft) }\end{array}$ & $\begin{array}{l}\text { Institutional } \\
\text { failures }\end{array}$ \\
\hline Market structures & & & $\begin{array}{l}\text { Poorly articulated } \\
\text { demand; } \\
\text { Economies of scale }\end{array}$ & & & $\begin{array}{l}\text { Copy Knowledge; } \\
\text { Negative } \\
\text { Externalities }\end{array}$ & Market structure & \\
\hline Capability problems & $\begin{array}{l}\text { Information and } \\
\text { absorptive } \\
\text { deficiencies of } \\
\text { enterprises }\end{array}$ & & & Capabilities' failure & $\begin{array}{l}\text { Capability and } \\
\text { learning problems }\end{array}$ & & Capacities & \\
\hline $\begin{array}{l}\text { Knowledge and physical } \\
\text { infrastructure }\end{array}$ & & $\begin{array}{l}\text { Failures in } \\
\text { infrastructural } \\
\text { provision and } \\
\text { investment }\end{array}$ & & $\begin{array}{l}\text { Infrastructural } \\
\text { failures }\end{array}$ & $\begin{array}{l}\text { Infrastructure } \\
\text { provision and } \\
\text { investment } \\
\text { problems }\end{array}$ & & $\begin{array}{l}\text { Infrastructure } \\
\text { (knowledge); } \\
\text { infrastructure } \\
\text { (physical) }\end{array}$ & $\begin{array}{l}\text { Failures in } \\
\text { infrastructural } \\
\text { provision and } \\
\text { investment }\end{array}$ \\
\hline $\begin{array}{l}\text { Too weak and too strong } \\
\text { interactions }\end{array}$ & $\begin{array}{l}\text { Lack of interaction } \\
\text { between actors }\end{array}$ & & $\begin{array}{l}\text { Poor connectivity; } \\
\text { Wrong guidance } \\
\text { for future markets }\end{array}$ & $\begin{array}{l}\text { Interaction } \\
\text { failures: } \\
\text { Strong network } \\
\text { failures and } \\
\text { Weak network } \\
\text { failures }\end{array}$ & $\begin{array}{l}\text { Network prob- } \\
\text { lems/unbalanced } \\
\text { exploration-exploitation } \\
\text { mechanisms; } \\
\text { complimentarity } \\
\text { problems }\end{array}$ & & $\begin{array}{l}\text { Interaction (too } \\
\text { strong); Interaction } \\
\text { (too weak) }\end{array}$ & \\
\hline Transition failure & & Transition failures & & & $\begin{array}{l}\text { Transition } \\
\text { problems }\end{array}$ & & & Adaptation failures \\
\hline Lock-in & & Lock-in failures & $\begin{array}{l}\text { Local search } \\
\text { processes }\end{array}$ & & Lock in problems & & & Lock-in failures \\
\hline Directional & & & & & & & & Directional \\
\hline Demand articulation & & & & & & & & $\begin{array}{l}\text { Demand } \\
\text { articulation }\end{array}$ \\
\hline Institutional coordination & & & & & & & & $\begin{array}{l}\text { Institutional } \\
\text { coordination }\end{array}$ \\
\hline Reflexivity & & & & & & & & Reflexivity \\
\hline
\end{tabular}


Table 2

Overview of cases per country and technology.

\begin{tabular}{|c|c|}
\hline Country & Technology \\
\hline Australia & CCS \\
\hline \multirow[t]{2}{*}{ Austria } & Biogas \\
\hline & Green power \\
\hline Canada & CCS \\
\hline Denmark & Wind, Biogas (x3) ${ }^{a}$ \\
\hline \multirow[t]{5}{*}{ Germany } & Wind $(x 5)$ \\
\hline & Solar (x2) \\
\hline & Biogas $(x 2)$ \\
\hline & Stationary fuel cells \\
\hline & Micro-CHP \\
\hline \multirow[t]{13}{*}{ Netherlands } & Biogas $(\mathrm{x} 4)$ \\
\hline & BM cofiring $(\mathrm{x} 2)$ \\
\hline & Heat-pump \\
\hline & Wind $(x 6)$ \\
\hline & BM gasification \\
\hline & $\mathrm{CHP}(\mathrm{x} 2)$ \\
\hline & Biofuels (x6) \\
\hline & BM Digestion \\
\hline & BM combustion \\
\hline & $\mathrm{PV}(\mathrm{x} 3)$ \\
\hline & $\mathrm{H} 2$ \\
\hline & ANG \\
\hline & CCS \\
\hline Norway & CCS \\
\hline Spain & Wind \\
\hline \multirow[t]{8}{*}{ Sweden } & Wind $(x 5)$ \\
\hline & Solar/solar collectors $(\mathrm{x} 4)$ \\
\hline & Biofuels (x3) \\
\hline & Biopower \\
\hline & $\mathrm{CHP}$ \\
\hline & Small biofuel boilers (nuclear and hydropower) \\
\hline & Pellet burner \\
\hline & BM gasification \\
\hline Switzerland & Biogas \\
\hline \multirow[t]{5}{*}{ UK } & Wind (x2) \\
\hline & Marine (x2) \\
\hline & PV \\
\hline & $\mathrm{BM}$ \\
\hline & $\mathrm{CHP} /$ micro-CHP \\
\hline \multirow[t]{2}{*}{ US } & Wind $(\mathrm{x} 2)$ \\
\hline & CCS \\
\hline
\end{tabular}

a The numbers depicted in brackets are the number of studies done on that particular technology; Wind in Germany, the Netherlands and Sweden are the most often studied cases.

overview of country and technology per theoretical framework applied).

For our analysis we first identify all barriers and problems described in the case studies and include these in a database. Each barrier is then allocated to a single systemic problem category. The allocation of the empirical data to the systemic problems has been verified and repeated independently by other researchers to improve the reliability. This analysis provides insight in the most common type of barriers (for each technology) and gives more insights in the specific form of each system problem in the case of RETs.

\section{Review of systemic problems for renewable energy technologies}

Table 3 shows the allocation scheme for the systemic problems that has been developed in an inductive and iterative way. The third column shows the amount of barriers per systemic problem extracted from the empirical data. As mentioned in Table 2 some cases are studied by several authors. Nonetheless, the double counting has not been corrected for in the third column as this is a literature review and the numbers merely serve as an illustration of the relative attention for each systemic problem in the literature. The systemic problem that has been observed most often is 'hard institutional problems', followed by 'market structure problems', 'soft institutions' problems, etc. Below the individual systemic problems will be described with specific examples from the case studies.

\subsection{Hard institutional problems}

In the case studies we observed the following hard institutional problems.

The first problem relates to 'stop and go'-policies: about 37 distinct cases report on highly volatile developments in regulations and subsidy schemes. Subsidies are announced but the actual implementation is often delayed or the implemented subsidy scheme has lower tariffs or shorter time periods than agreed upon before. The worst example of such stop and go policies comes from the Netherlands where in the period 1998-2001 every 2 years subsidies for RETs were stopped and reintroduced in an alternative form which eventually was also stopped shortly after (1998 start energy tax REB, 2001 stop energy tax; 2002 promised introduction of RETs subsidy called MEP; 2003 actual introduction of MEP with lower tariffs and 10 years duration instead of 20 years; 2006 unannounced stop of MEP; 2007 start new subsidy scheme called SDE; 2009 stop SDE; 2011 start adapted SDE called SDE+) [5,40-43]. The same trend of 'stop and go' approach of subsidy programmes is observed in the UK for the cases of micro-CHP, wind, PV, biomass, and marine energy $[3,44,45]$. Also in Sweden similar dynamics were reported related to solar collectors [46], biopower [47], and pellet burners [2]. The case studies described above conclude that such an uncertain policy environment makes entrepreneurs and investors reluctant to take the risk and invest in RETs, which undermines the position of the government and policy makers in terms of reliability and trustworthiness. This lack of trust in the government does not only negatively influence current RETs trajectories but also future RETs trajectories.

A second observed phenomenon is the attention shift of policy makers with respect to a technology or its application context. In the case of micro-CHP in the UK initial funding was provided in order to meet the challenges of energy security, but then the issues of liberalisation and privatisation of the energy market started to dominate the policy debate which negatively influenced support for CHP [45]. Another example is the case of biomass digestion in the Netherlands. Biomass digestion received very unstable attention due to rapid changes in the priority of societal problems. In the 1970s the manure surplus problem was dominant, followed by the waste surplus problem in the 1980s and climate change in the 1990 s $[4,5,48]$. Unfortunately, every change led to a temporary decline in policy attention for biomass digestion. In the case of biofuels the changing policy preferences regarding first and second generation biofuels became apparent $[43,49]$. The same was observed for solar cells in the Netherlands. During the 1970-1980s the focus was on sunny and developing countries while in the $1990 \mathrm{~s}$ climate change dominated the agenda and PV was also seen as an option for North West European countries. Very recently this perspective changed again and PV is not any longer considered a viable option due to high costs [42,50]. Also in Sweden policy perspectives changed. For example biofuels received attention in the 70-80s due to oil crises and during the 90s due to air pollution [51].

As a third institutional failure many articles mention misalignment between policy levels, different sectors and existing and new institutions: for the biofuels case in the Netherlands [43,49,51,52] and the PV case in the Netherlands [42] shows a misalignment between different levels of government; in both cases the provincial (regional) governments strongly stimulate local activities with tax exemptions for biofuel applications and subsidies for solar production firms, whereas the national government hinders the development and diffusion of those technologies with 
Table 3

Allocation scheme of systemic problems.

\begin{tabular}{|c|c|c|}
\hline Systemic problems & Empirical sub categories & No. of cases \\
\hline Hard institutions & $\begin{array}{l}\text { 1. 'Stop and go policy': lack of continuity and long-term regulations; inconsistent } \\
\text { policy and existing laws and regulations } \\
2 \text {.' Attention shift': policy makers only support technologies if they contribute to } \\
\text { the solving of a current problem } \\
\text { 3. 'Misalignment' between policies on sector level such as agriculture, waste, and } \\
\text { energy, and on governmental levels, i.e. EU, national, regional level, etc. } \\
\text { 4. 'Valley of Death': lack of subsidies, feed-in tariffs, tax exemption, laws, emission } \\
\text { regulations, venture capital to move technology from experimental phase towards } \\
\text { commercialisation phase }\end{array}$ & 51 \\
\hline Market structures & $\begin{array}{l}\text { 1. Large-scale criteria } \\
\text { Incremental/near-to-market innovation } \\
\text { Incumbents' dominance }\end{array}$ & 30 \\
\hline Soft institutions & $\begin{array}{l}\text { 1. Lack of legitimacy } \\
\text { Different actors opposing change }\end{array}$ & 28 \\
\hline Capabilities/capacities & $\begin{array}{l}\text { 1. Lack of technological knowledge of policy makers and engineers } \\
\text { Lack of ability of entrepreneurs to pack together, to formulate clear message, to } \\
\text { lobby to the government } \\
\text { Lack of users to formulate demand } \\
\text { Lack of skilled staff }\end{array}$ & 19 \\
\hline Knowledge infrastructure & $\begin{array}{l}\text { - Wrong focus or no specific courses at universities and } \\
\text { knowledge institutes } \\
\text { - Gap/Misalignment between knowledge produced at universities } \\
\text { and what needed in practice }\end{array}$ & 16 \\
\hline Too weak interactions & $\begin{array}{l}\text { - Individualistic entrepreneurs } \\
\text { - No networks, no platforms } \\
\text { - Lack of knowledge diffusion between actors } \\
\text { - Lack of attention for learning by doing }\end{array}$ & 13 \\
\hline Too strong interactions & $\begin{array}{l}\text { - Strong dependence on government action or dominant partners (incumbents) } \\
\text { - Network allows no access to new entrants }\end{array}$ & 8 \\
\hline Physical infrastructure & $\begin{array}{l}\text { - No access to existing electricity or gas grid for RETs } \\
\text { - No decentralised, small-scale grid } \\
\text { - No refill infrastructure for biofuels, ANG, H2, biogas }\end{array}$ & 2 \\
\hline
\end{tabular}

the discontinuation of subsidy programmes on national level and explicit statements of not supporting these technologies $[5,40,41,43,49]$.

Another misalignment occurs when regulations between sectors are contradictory and therefore hamper the development and diffusion of the technology in question; especially for biomass technology where the agricultural, energy and waste sector are involved many conflicting and contradictory regulations were observed (see cases biofuels in the Netherlands $[43,49,52,53]$, biomass digestion in the Netherlands $[4,5,48]$ and biomass digestion in Switzerland [54]).

The final hard institutional problem is the lack of institutional support during the so-called valley of death. The valley of death is the phase in the technology life cycle just before market introduction. In this phase high uncertainties about market success are coupled with high investment costs for building production capacity. In the case of RETs in the UK R\&D efforts and support schemes offer small and protected niche markets that allow early demonstrations and to move into pre-commercial trials. However a gap between existing RD\&D programmes and the 'near commercial' support offered by the renewable obligations do not manage to overcome the valley of death. The consequence is that many RETs are stuck in the R\&D or early demonstration stage, unable to move into pre-commercial trials [3,55]. The same trend is observed in the Netherlands were large budgets for R\&D are provided but hardly any instruments are available for large scale demonstrations and early market formation. This proved to be problematic for biomass, biofuels, wind and PV technologies [5,40-43,49,50,56-59]. For Sweden the same observation was made $[20,46]$. Countries such as Germany, Austria and Denmark have shown good practices in this area by maintaining a feed-in system over a long period of time that has been altered over the years in agreement with the renewable energy sector which resulted in a large-scale implementation of renewable energy technologies such as biomass, PV and wind energy $[20,60-66]$.

\subsection{Market structures}

Renewable energy technologies have a hard time to break through in the energy market dominated by fossil fuel technologies that reap the benefits from economies of scale, long periods of technological learning and socio-institutional embedding. This makes them cheap, efficient, produced in large quantities and optimally aligned to institutions and customer and firm preferences. In the search for alternative energy technologies, the technological characteristics of fossil fuels are mirrored to renewable technologies. Even though they are technologically fundamentally different, the same fossil fuel heuristics are applied to renewables. Also powerful incumbent firms play - unintentionally or not - problematic roles. More specifically, the following market structure problems were observed in the literature.

First, the incompatibility of RETs with the paradigm of large-scale centralised generation is problematic. Especially in the wind energy cases the first choice is large-scale wind turbines (MWs). Typical examples are the case of Vattenfall in Sweden [2], the Californian wind case [67] and the Dutch wind case [20,50,56], where premature convergence towards large-scale wind turbines led to poor technological designs, unreliable technology and therefore problematic diffusion of the technology. But also in other technologies the current technological paradigm [68] directed the search towards large scale design; for biomass gasification [40] and heat pumps [4] over dimensioned designs were chosen, which were unfeasible in practice hampering technology diffusion. In success cases (such as wind in Denmark) the initial choices for small scale technologies was followed by continuous technological learning and steady up scaling of designs $[65,69,70]$. 
Another typical problem for RETs is the choice for incremental innovations and near to market innovation that fit best in current energy systems. By itself, this is not a problem, except for the fact that these technologies reduce the success chances of more radical and long term options. In many cases incremental innovation and near-market technologies are preferred and supported by policy, such as for the micro-CHP market in the UK which is dominated by incumbent players and long-established energy utilities [45]. The reason for the support is that micro-CHP fits well with the current structure of the gas grid and that incumbents offer domestic boiler service contracts, being close to their specific knowledge and skills base and providing them with a positive image without having to make radical changes [45]. These technological preferences have negative effects on the diffusion of for example solar cells and solar boilers [44]. In the Netherlands and other countries, such as Sweden and the UK, mainly biomass co-combustion is favoured and supported by policy. This is a very low-tech option; biomass is added to coal firing plants without having to make great alterations to the installations. Since this option is considered the cheapest option for the short turn, it deviates investments from more long term solutions and at the same time increases the lock-in of coal in the energy system $[3,40,41,47,71]$.

The last observed problem related to market structures is the negative attitude and strategy of incumbent firms related to renewable energy. This strategy can be summarised as raising expectations about the important role of incumbent in the transition to a sustainable energy system while in reality very limited activities are pursued in this area. In the case of wind energy in the UK about $80 \%$ of the wind power installations are owned by large utility companies; their strategies being to buy up independent developers. In this way the technology does not provide a fundamental threat to their core businesses [66]. The micro-CHP market in the UK is dominated by incumbent players and long-established energy utilities in order to benefit from the positive image effects and to position themselves in a potential future business field and new retail products: lease of micro-generation units [45]. Similarly, the Swedish Energy company Vattenfall made investments in RD\&D and stated its commitment to renewable energy sources but they only bought four commercial wind turbines in 1990 and only 30 in 1998 [2].

Summarising, these examples show that in the energy sector the incumbent technologies, actors and institutions are very powerful and well organised. Incumbents are not only hesitant towards adopting new technologies but may also deliberately attempt to block the development of new emerging technologies [72]. This form of dynamics can logically be expected due to the interests of incumbents in the current energy system, but unfortunately they are granted a large influence by policy makers when renewable energy policies are designed.

\subsection{Soft institutional problems}

Legitimacy is a matter of social acceptance and compliance with relevant institutions [73], and for new technologies gaining legitimacy is often a slow and tedious process. In many cases of low-carbon innovation, existing institutions tend to block the development of new technological options [74]. The current system does not facilitate low carbon innovations and the emerging innovation system is not able yet to build up a strong legitimacy. In addition, opponents hamper and break down the legitimacy of emerging innovations. Therefore it is necessary to attain legitimacy in order for resources to be mobilised, for demand to form and for actors in the new innovation system to acquire political strength in order to influence the institutional setting [73,75]. Legitimacy is not given but rather formed through conscious actions by various organisations and individuals in a socio-political process of legitimation, which incorporates cognitive, normative as well as regulative aspects [73]. Actors can de-legitimise technologies with respect to three dimensions: the performance of each unit (e.g. in terms of environmental impact), the potential (physically, technically or economically) and the proven functionality (in terms of technology and cost) [73]. Besides incumbents, there are also other actors that can (de)-legitimise a technology according to their interests, for example media, inhabitants or environmental groups.

We will now focus on the arguments that are often used to delegitimise renewable energy technologies. The most typical example is the resistance to wind power. In The Netherlands the resistance mainly comes from electricity production companies due to the small amount of electricity produced by wind turbines compared to conventional gas-driven power plants or nuclear power plants; furthermore due to the large national gas supply the utilities used the argument that no energy diversification is needed [20,46,61]. Other arguments used are the operational problems, 'horizon pollution' and bird killing [56,72]. In the US the initially strong legitimacy of the turbine industry is not further developed due to siting issues $[67,76]$. In Sweden legitimacy lacks completely due to negative communication of media (wind power contribution being 'small' or 'smaller than some other electricity source') and lack of a forceful way of counteraction by policy makers [72]. In the case of PV in the Netherlands, the government mainly sees a role for PV in the far future, i.e. after 2020, as the expectations are that PV will reach consumer price levels only over 10 years of time. Therefore mainly R\&D activities are supported and financed by the government [42]. In the UK especially siting issues and the 'Not In My Back Yard' (NIMBY) phenomenon hamper the construction of wind parks [3]. This same phenomenon also hampers the construction of biomass plants in The Netherlands $[5,40,41,77]$.

We now focus on the unexpected role of certain actors and parties to act as advocates or opponents. An example is the strong lobby against biofuels by environmental agencies as the cultivation of energy crops leads to rising food prices and deforestation of vulnerable natural areas like rainforests $[43,49]$. In the case of cofiring, environmental groups and local residents oppose the wide diffusion of co-firing and problems with permit procedures slow down the process $[41,78,50]$.

These examples show that support and opposition for renewable energy technologies is not stereotypically bounded to specific actor groups in the innovation system. Unique combinations of advocates and opponents arise under different circumstances. As a result different studies on wind, biomass, micro-CHP and PV in Germany [41,61,63,66,76], biogas in Switzerland [54] and wind and biogas Denmark $[20,48,65,79]$ conclude that transparent and early communication to all stakeholders involved about the risks and benefits of the technology and construction plans are crucial in order to increase the social acceptance for those technology.

\subsection{Capabilities/capacities}

Lack of capabilities, such as the lack of appropriate knowledge and skills can be found among all actors within the innovation system. For example, (1) lack of technological knowledge of policy makers and engineers; (2) lack of ability of entrepreneurs to pack together, to formulate a clear and realistic message and to lobby to the government; (3) Lack of capabilities by users to formulate demand; and (4) lack of skilled staff.

In the case of a lack of technological knowledge many examples are reported in the literature of wrong technological choices, poor designs and malfunctioning technology. Examples are large wind turbine designs $[2,20,56,67,50]$ over-dimensioned heatpumps [4] and large-scale biomass pilot plant $[4,40]$.

The second capability that is often missing is the capability of entrepreneurs to pack together and lobby for their technology. The 
most common observation is that entrepreneurs already compete in a very early stage with each other, instead of forming coalitions and alliances in order to be more influential with respect to changing regulations, obtaining resources and creating a niche market. In the case of first and second generation biofuels advocates vigorously compete with each other instead of targeting the incumbent technology. This struggle contributes to the uncertainty surrounding both technologies and the field experiences serious legitimacy problems concerning the sustainability of the technology $[43,49,52,53]$. The same competition between entrepreneurs is also observed for several biomass technologies - combustion versus gasification versus digestion - in the Netherlands $[4,5,40,41,57,58]$, in Sweden [2,47] and the UK [3] as well as for solar collectors entrepreneurs in Sweden [2]. Only after encountering difficulties, disappointments and lack of support from government do entrepreneurs select more cooperative strategies. In Germany and Denmark, two success stories related to renewables, much more cooperative strategies are observed among entrepreneurs, as well as in the fuel cell case in Germany where formal networks are set up [80]; biomass digestion in Germany where a biogas association represents the needs of the sector and lobbies to the government [64]; the micro-CHP sector in Germany was also set up of formal networks [45]; as well as wind in Germany [61,66,76]; and biogas in Denmark where dedicated networks were set up [65].

Another entrepreneurial capability that is often reported lacking is the capability to formulate realistic expectations. Too inflated expectations lead to the situation that they cannot be fulfiled, disappointment and lack of trust by other actors in the innovation system. In the case of biomass gasification the expectations were so high-strung due to promises of unrealistic short term development times and technological potentials, that once the technology could not deliver what was promised, the government and investors stopped their support and the biomass gasification innovation system collapsed $[40,77]$. Similar developments were observed for the development of hydrogen and fuel cell development around the turn of the millennium where too high strung expectations about technological potentials and short-term market introduction resulted in the blow out of the hydrogen car $[81,82]$.

\subsubsection{Lack of demand}

In the study of [2] on several renewable energy technologies in Sweden such as wind turbines, solar collectors and equipment for biomass combustion and gasification they found that new customers lack the competence to articulate their demand. Actors such as country council purchasers who usually buy standard products, or single-house owners who have to change their boilers once in 30 years, are not used to make such decisions and therefore to articulate their demand. The role of intermediaries that formulate the demand is crucial. However, expect of in the wind power field such intermediaries are lacking [2]. For many other studies it can be expected that the lack of demand also forms a problem due to the inexperience of actors in having to make such decision in whether they want to invest in micro-CHP, PV, small biofuel boilers, pellet burners or biopower $[2,42,45-47]$.

\subsubsection{Lack of skilled staff}

Another lack of capabilities is the shortage or lack of skilled staff. When innovations radically differ from existing ones, one may expect this problem to occur since the new technological trajectory requires new educational programmes and it takes a long time for the educational system to pick up these changes. Second, the speed of development of new sectors is also likely to create a shortage in trained and skilled personnel. Within the Dutch PV innovation system an increasing scarcity of skilled (technical) personnel is acknowledged [42]. There is a lack of expertise and skills on how to install PV panels on the house roofs and to connect the PV systems to the electricity grid, since the Dutch PV sector has been inactive since 2003. Experts predict that it will take several years before the sector is back on track in order to realise the wished for large-scale implementation $[83,84]$. Also in the wind and microCHP industry in the UK [3] the same observations are made, where the low numbers of accredited installers limit the diffusion of the new technology [45].

\subsection{Knowledge infrastructure}

Many studies report that there is a gap between the knowledge produced at university and what is needed in practice. In the study by Foxon et al. [3] biomass technologies suffer from high levels of technology and business risk; this is exacerbated by a lack of understanding among actors and problems with knowledge flow throughout the innovation system [3]. The interaction between universities and industry are very limited and a lack of strategic direction in research fails to increase the cooperation between universities and industry [3]. The knowledge to solve technological problems is mostly present in the system but due to lack of information exchange many problems remain unsolved [85].

In the case of Dutch wind turbines it was very difficult to turn knowledge into well-functioning wind turbines and market opportunities. Wind turbines have their own characteristics, and models and theories from the aerospace industry could not be used without significant adjustment. The Danish case showed a best practice example. In this case small wind turbine manufacturers gradually improved and scaled up the turbines and in interaction with users managed to solve problems and learn from them [56].

\subsection{Too weak and too strong interaction problems}

The diffusion of knowledge is important in a new system involving many actors, some of which are small and poor in resources. By connecting different actors and facilitating knowledge flows, improvements and acceleration in the technical development, reduction of uncertainty, understanding among different actors and articulation of a collective demand are facilitated. This again contributes to the build up of an innovation system and therefore the diffusion of the new technology. In the work of Bergek [85] and Johnson and Jacobsson [2] poor or too strong connectivity and network failures are identified as blocking mechanisms in the field of RETs. In the case of Dutch wind turbines too strong connectivity resulted in strategic conformity with respect to market and technology choices and thus in increased vulnerability to uncertainty [85]. However weak learning networks between potential customers and capital goods suppliers as well as between the capital goods industry and academia made it difficult to handle technological and market uncertainty.

The case of small biofuel boilers in Sweden is characterised by poor connectivity and fairly individualistic, unwilling entrepreneurs to cooperate and share knowledge with other firms. Furthermore there are weak relationships between small RETs firms and firms providing related products and services and between users and academia (large cultural distance). Due to weak connectivity between actors positive external economies will not be generated properly.

In a study on marine energy in the UK it was observed that this technology was driven by a few small developer firms with only limited links between developers, component suppliers and universities [55].

Another example of too strong interactions comes from Sweden where Swedish tax legislation is biased against the production of electricity in CHP generation plants, due to the strong interaction between policy makers and utilities that favour large scale nuclear and hydroelectric power. 
The last example also comes from Sweden where the solar collectors market is dominated by supplier industry and the traditional installation industry that are antagonistic to new entrants. A quality certification procedure for solar collectors was developed partly as means to eliminate small, 'unprofessional' producers from the market.

\subsection{Physical infrastructure}

For companies to succeed they need a reliable infrastructure to enable everyday operations and support their long-term developments. However for renewable energy technologies different and specific infrastructure is needed than the current electricity, gas or gasoline infrastructure. This failure can manifest itself in two ways: either in the absence of the infrastructure or denied access to the current infrastructure.

Typical examples that show the important role of infrastructure absence are related to new automotive fuels. The introduction of renewable automotive fuels is strongly dependent on the availability of an initial infrastructure. Different studies report the slow diffusion of alternative fuels when a refuelling infrastructure is not developing quickly enough $[43,49,82]$.

A clear case that shows that existing infrastructures can also be used strategically by incumbents to slow down the diffusion of renewables is the Dutch biomass digestion case. The digestion of biomass leads to the production of methane, which is also the main substance of natural gas. For Dutch farmers that produce biogas from biomass digestion on their farms, access to feed in their biogas into the national gas grid was denied by natural gas grid owners, due to the differing quality of the biogas (65-70\% methane) and the Dutch natural gas (80\% of methane) [86]. Smink et al. [87] report a similar example in the case of automotive biofuels. In this case a quality standard for biofuels is agreed upon by mainly incumbent fossil fuel actors that require biofuels entrepreneurs to make additional investments in 'upgrading' the biofuel so that it may be blended with conventional gasoline and diesel.

\section{Discussion and conclusion}

The literature review shows that systemic problems hamper the rapid development and diffusion of renewable energy technologies and therefore need additional attention from policy makers and other system actors that have an interest in speeding up the diffusion of renewable energy. The literature review shows that a lack of stable institutions, hard as well as soft ones that stimulate renewables, and a poor alignment of these institutions with practices in other sectors and regional/local institutions are key systemic problems. These systemic problems are the most reoccurring barriers in the empirical cases. It needs to be noted though that a certain bias exists in the case of RETs, as the government plays a dominant role in stimulating or steering such transformations in order to reach societal goals and to bring about this transformative change. Therefore a larger focus on institutional aspects is highlighted in these socio-technical studies.

As can be expected from systems theory the systemic problems are not independent. Malfunctioning parts of the system invoke problems in other parts of the system. For example, the institutional problems are strengthened by problematic knowledge infrastructures and too weak and strong interactions between different actor groups in the innovation systems. Furthermore, the reason for why the systemic problem hard institutions occur so often can partly be explained by the lack of capabilities of several actors. Due to the lack of technological knowledge by policy makers, but also the lack of capabilities of entrepreneurs to pack together and formulate a uniform message about the kind of support they need from government, a lack or misalignment of regulations occurs that blocks the development and diffusion of RETs or strengthens 'lock-in' into the fossil fuel based system. Therefore it is important for several systemic problems to be targeted by different actor types in a coherent manner in order to avoid more systemic problems that trigger and reinforce each other.

As mentioned earlier there are different types of actors who seek to stimulate these transitions such as policy makers, entrepreneurs (but also incumbents in some cases), and NGO's; however these same actors can also (unintentionally) form a barrier. In our review the problematic role of incumbents has come to the forefront. Here policy makers should be aware of the motivations and intentions why incumbents want to join the policy arena about RETs. On the other hand we also observed specific problems associated with strategies of renewable energy entrepreneurs. They often pursue short term individually oriented strategies instead of strategies more oriented towards the build up of innovation systems. In more innovation system research, a special type of actor has been identified who may fulfil the role of a system builder. A system builder is an actor that (consciously) seeks to contribute to the innovation system build up and to strengthen the key processes (functions) in an innovation system [88]. The goals of system building entrepreneurs are generally broader than the goals of non-system building entrepreneurs in the system as they not only seek survival, or maximum profits, for themselves but also the development of a well-functioning innovation system. Therefore entrepreneurs should also be aware of their role and the influence they can exert in stimulating transitions.

Finally we end with specific policy recommendations that follow from this literature review. First, in order to avoid hard institutional failures, it is necessary to focus on specific technological systems which require specific policy measures. Differences in policy needs are determined by the phase the innovation system is in, the specific problems related to the technology, acquisition of financial resources, distance to market, strength of the networks, international playing field, etc. This implies that 'one model fits all' is not likely to work. The consequence is that innovation policy makers need to develop the appropriate capabilities to evaluate the specific circumstances of an individual innovation system and the specific problems that are related to specific technological fields.

A second way to avoid hard institutional failures is to develop a consistent and long term policy to stimulate the formation of new innovation systems. Ad hoc policy initiatives increase uncertainties for the entrepreneurs, engineers, venture capitalist and other actors in the innovation system therefore decreasing the success chances of innovation system development as observed in many case studies. Long term and consistent policy does not mean that policy instruments cannot change over time. In fact, due to the changes in the needs of the actors in the innovation system, a continuous reflection on the effects of policy measures on the innovation system and subsequent alteration is necessary as is shown in the case of German feed-in law.

Third, to overcome the failure of too strong networks or interactions, it is necessary for policy makers to listen carefully to new entrants and often small innovative firms. This is not an easy task since most lobby networks are dominated by large incumbent firms. New entrants often find large obstacles when trying to enter these lobby networks. Their message is therefore not easy to hear and mostly outweighed by de-legitimising arguments. Moreover, when policy instruments are designed in favour of these emerging innovation systems, fierce opposition can be expected from the old regime. The Dutch experience shows that policy makers have a strong preference to keep lobby networks in place by trying to persuade the incumbent firms to develop sustainable innovations. Very often, new entrants are not at the table when new policy measures are designed. Therefore policy makers also need to develop capabilities in order to shape expectations and visions for the future 
of a specific technology in order to draw in the new entrants and provide space and time for them to formulate their needs.

Finally in order to avoid market structure failures, it is necessary to put pressure on the incumbent locked-in system as otherwise new technologies have to comply with the criteria's that are used to measure the performance of incumbent technologies. This increases the success chances of the emerging innovation systems as the products of these innovation systems have better chances within the old system. In this case the generic policy instruments favoured by neoclassical trained policy makers might be useful; however the will is needed to apply the instruments in that way.

\section{References}

[1] IEA, RD\&D Budget, IEA Energy Technology R\&D Statistics (database), 2011; 2010.

[2] Johnson A, Jacobsson S. Inducement and blocking mechanisms in the development of a new industry: the case of renewable energy technology in Sweden. In: Coombs R, Green K, Richards A, Walsh V, editors. Technology and the market. Demand, users and innovation,. Cheltenham: Edwar Elgar Publishing Ltd.; 2000. p. 89-111.

[3] Foxon TJ, Gross R, Chase A, Howes J, Arnall A, Anderson D. UK innovation systems for new and renewable energy technologies: drivers, barriers and systems failures. Energy Policy 2005;33:2123-37.

[4] Raven R, Verbong GPJ. Ruling out innovations - technological regimes, rules and failures: the cases of heat pump power generation and bio-gas production in The Netherlands. Innovation Management, Policy and Practice 2004;6:178-98.

[5] Negro SO, Hekkert MP, Smits REHM. Explaining the failure of the Dutch innovation system for biomass digestion - a functional analysis. Energy Policy 2007;35:925-38.

[6] Valentina D. Biomass power: exploring the diffusion challenges in Spain. Renewable and Sustainable Energy Reviews 2009;13:1551-9.

[7] Rao KU, Kishore VVN. A review of technology diffusion models with special reference to renewable energy technologies. Renewable and Sustainable Energy Reviews 2010;14:1070-8.

[8] del Río P, Unruh G. Overcoming the lock-out of renewable energy technologies in Spain: the cases of wind and solar electricity. Renewable and Sustainable Energy Reviews 2007;11:1498-513.

[9] Söderholm P, Ek K, Pettersson M. Wind power development in Sweden: global policies and local obstacles. Renewable and Sustainable Energy Reviews 2007; 11:365-400.

[10] Paolo A. Factors influencing the likelihood of regulatory changes in renewable electricity policies. Renewable and Sustainable Energy Reviews 2008;12:141-61.

[11] OECD. OECD factbook 2010: economic, environmental and social statistics; 2010.

[12] Arrow K. Economic welfare and the allocation of resources for invention; 1962.

[13] Smith K. Innovation as a systemic phenomenon: rethinking the role of policy. Enterprise \& Innovation Management Studies 2000;1:73-102.

[14] Hughes TP. Networks of power: electrification in western society, 1880-1930. Baltimore: The Johns Hopkins University Press; 1983.

[15] Geels F, Hekkert M, Jacobsson S. The dynamics of sustainable innovation journeys. Technology Analysis and Strategic Management 2008;20:521-36.

[16] Christensen CM, Rosenbloom RS. Explaining the attacker's advantage: technological paradigms, organizational dynamics, and the value network. Research Policy 1995;24:233-57.

[17] Christensen CM. The innovator's dilemma. Harvard Business School Press Boston; 1999.

[18] Kemp R, Schot J, Hoogma R. Regime shifts to sustainability through processes of niche formation: the approach of strategic niche management. Technology Analysis and Strategic Management 1998;10:175-95.

[19] Van de Ven AH, Polley DE, Garud R, Venkataraman S. The innovation journey. Anonymous Oxford University Press; 1999.

[20] Jacobsson S, Johnson A. The diffusion of renewable energy technology: an analytical framework and key issues for research. Energy Policy 2000;28:625-40.

[21] Klein Woolthuis R, Lankhuizen M, Gilsing V. A system failure framework for innovation policy design. Technovation 2005;25:609-19.

[22] Nill J, Kemp R. Evolutionary approaches for sustainable innovation policies: from niche to paradigm. Research Policy 2009;38:668-80.

[23] Van Mierlo B, Leeuwis C, Smits R, Klein Woolthuis R. Learning towards system innovation: evaluating a systemic instrument. Technological Forecasting and Social Change 2010;77:318-34.

[24] Farla J, Alkemade F, Suurs RAA. Analysis of barriers in the transition toward sustainable mobility in the Netherlands. TFSC 2010;77:1260-9.

[25] Wieczorek AJ. A systemic policy framework. Methodological considerations. Paper presented at the 1 st international conference on sustainability transitions, Amsterdam, June 2009; 2009.

[26] Alkemade F, Hekkert MP, Negro SO. Transition policy and innovation policy: friends or foes. EIST 2011:1:125-9.

[27] Weber M, Rohracher $H$. A systems approach to transition dynamics: providing a foundation for legitimizing goal-oriented policy strategies. Paper presented at the EASST 2010 conference, Trento, 1-4 September 2010; 2010.
[28] Edquist C. Systems of innovation. London: Technologies, Institutions and Organisations, Pinter; 1997.

[29] Lundvall B. Introduction. In: Lundvall B, editor. National systems of innovation - toward a theory of innovation and interactive learning,. London: Pinter; 1992. p. $1-19$.

[30] Nelson R. National systems of innovation: a retrospective on a study. Industrial and Corporate Change 1992:347-74.

[31] OECD. Managing national innovation systems. Organisation for Economic Cooperation and Development; 1999.

[32] Edquist C, Hommen L. Systems of innovation: theory and policy for the demand side. Technology in Society 1999;21:63-79.

[33] OECD. National innovation systems; 1997.

[34] Lipsey RG, Carlaw K, Bekar C. Economic transformations: general purpose technologies and long-term economic growth. USA: Oxford University Press; 2005.

[35] Arthur B. Competing technologies: an overview. In: Dosi GEA, editor. Technical change and economic theory. London: Francis Printer; 1988. p. 590-607.

[36] Erickson WB, Maitland I. Healthy industries and public policy. In: Dutton ME editor. Industry vitalization. New York: Pergamon Press; 1989.

[37] Andersson BA, Jacobsson S. Monitoring and assessing technology choice: the case of solar cells. Energy Policy 2000;28:1037-49.

[38] Afuah AN, Utterback JM. Responding to structural industry changes: a technological evolution perspective. Industrial and Corporate Change 1997;6:183-202.

[39] Anderson P, Tushman ML. Technological discontinuities and dominant designs: a cyclical model of technological change. Administrative Science Quarterly $1990 ; 35$.

[40] Negro SO, Suurs RAA, Hekkert MP. The bumpy road of biomass gasification in the Netherlands: explaining the rise and fall of an emerging innovation system. Technological Forecasting and Social Change 2008;75:57-77.

[41] Negro SO, Hekkert MP, Smits REHM. Stimulating renewable energy technologies by innovation policy. Science and Public Policy 2008;35.

[42] Negro SO, Vasseur V, Sark VWGJHM, Hekkert MP. Solar eclipse - the rise and 'dusk' of the Dutch PV innovation system. International Journal of Technology, Policy and Management 2011.

[43] Suurs RAA, Hekkert MP. Cumulative causation in the formation of a technological innovation system: the case of biofuels in the Netherlands. Technological Forecasting and Social Change 2009;76:1003-20.

[44] Foxon TJ, Pearson PJG. Towards improved policy processes for promoting innovation in renewable electricity technologies in the UK. Energy Policy 2007;35:1539-50.

[45] Praetorius B, Martiskainen M, Sauter R, Watson J. Technological innovation systems for microgeneration in the UK and Germany - a functional analysis. Technology Analysis and Strategic Management 2010;22:745-64.

[46] Jacobsson S, Bergek A. Transforming the energy sector: the evolution of technological systems in renewable energy technology. Industrial and Corporate Change 2004;13:815-49.

[47] Jacobsson S. The emergence and troubled growth of a 'biopower' innovation system in Sweden. Energy Policy 2008;36:1491-508.

[48] Geels FW, Raven R. Non-linearity and expectation in niche-development trajectories: ups and downs in Dutch biogas development (1973-2003). Technology Analysis \& Strategic Management 2006;18:375-92.

[49] Suurs RAA, Hekkert MP. Competition between first and second generation technologies: lessons from the formation of a biofuels innovation system in the Netherlands. Energy 2009;34:669-79.

[50] Verbong G, Geels F. The ongoing energy transition: lessons from a sociotechnical, multi-level analysis of the Dutch electricity system (1960-2004). Energy Policy 2007;35:1025-37.

[51] Hillman KM, Sandén BA. Exploring technology paths: the development of alternative transport fuels in Sweden 2007-2020. Technological Forecasting and Social Change 2008;75:1279-302.

[52] Ulmanen JH, Verbong GPJ, Raven RPJM. Biofuel developments in Sweden and the Netherlands. Protection and socio-technical change in a longterm perspective. Renewable and Sustainable Energy Reviews 2009;13: 1406-17.

[53] Hillman KM, Suurs RAA, Hekkert MP, Sandén B (with equal contributions by Suurs and Hillman) Cumulative causation in biofuels development: a critical comparison of the Netherlands and Sweden. Technology Assessment and Strategic Management 2008;20:593-612.

[54] Markard J, Stadelmann M, Truffer B. Prospective analysis of technological innovation systems: identifying technological and organizational development options for biogas in Switzerland. Research Policy 2009;38:655-67.

[55] Winskel M, McLeod A, Wallace R, Williams R. Energy policy and institutional context: marine energy innovation systems. Science and Public Policy 2006;33:365-76

[56] Kamp LM. Analyzing the introduction of renewable energy technologies in the Netherlands with the FIS approach - possibilities, limitations and additions; 2008.

[57] Raven R, Verbong G. Dung, sludge, and landfill - biogas technology in the Netherlands, 1970-2000. Technology and Culture 2004;45:519-39.

[58] Raven RPJM. Implementation of manure digestion and co-combustion in the Dutch electricity regime: a multi-level analysis of market implementation in the Netherlands. Energy Policy 2004;32:29-39.

[59] Van der Laak WWM, Raven RPJM, Verbong GPJ. Strategic niche management for biofuels: analysing past experiments for developing new biofuel policies. Energy Policy 2007;35:3213-25. 
[60] Decker T, Menrad K, Berenz S, Wagner R. Regulation and innovation in biogas technology in selected European countries. International Journal Public Policy 2007;2:89-108

[61] Bergek A, Jacobsson S. The emergence of a growth industry: a comparative analysis of the German, Dutch and Swedish wind turbine industries. In: Metcalf S, Cantner U, editors. Change, transformation and development, physica. Heidelberg: Springer; 2003. p. 197-228.

[62] Jacobsson S, Lauber V. The politics and policy of energy system transformation - explaining the German diffusion of renewable energy technology. Energy Policy 2006;34:256-76.

[63] Jacobsson S, Sanden BA, Bangens L. Transforming the energy sector - the evolution of the German technological system for solar cells. Technology Analysis \& Strategic Management 2004;16:3-30.

[64] Negro SO, Hekkert MP. Explaining the success of emerging technologies by innovation system functioning: the case of biomass digestion in Germany. Technology Analysis and Strategic Management 2008;20:456-82.

[65] Raven R, Gregersen KH. Biogas plants in Denmark: successes and setbacks. Renewable and Sustainable Energy Reviews 2007:11:116-32.

[66] Stenzel T, Frenzel A. Regulating technological change - the strategic reactions of utility companies towards subsidy policies in the German, Spanish and UK electricity markets. Energy Policy 2008;36:2645-57.

[67] Alkemade F, Kleinschmidt C, Hekkert M. Analysing emerging innovation systems: a functions approach to foresight. International Journal of Foresight and Innovation Policy 2007;3:139-68.

[68] Dosi G. Technological paradigms and technological trajectories. Research Policy 1982;11:147-62.

[69] Garud R, Karnøe P. Bricolage versus breakthrough: distributed and embedded agency in technology entrepreneurship. Research Policy 2003;32:277-300.

[70] Kamp LM, Smits REHM, Andriesse CD. Notions on learning applied to wind turbine development in the Netherlands and Denmark. Energy Policy 2004;32:1625-37.

[71] Raven RPJM. Towards alternative trajectories? Reconfigurations in the Dutch electricity regime. Research Policy 2006;35:581-95.

[72] Bergek A, Jacobsson S, Sanden B. 'Legitimation' and 'development of positive externalities': two key processes in the formation phase of technological innovation systems. Technology Analysis \& Strategic Management 2008;20:575-92.

[73] Bergek A, Jacobsson S, Sanden B. Key processes and policy challenges in the formation and early growth of a technology-specific innovation system: lessons from the field of renewable energy. Paper to be presented at the workshop
Understanding processes in sustainable innovation journeys, Utrecht, October 2-3, 2006; 2006.

[74] Unruh GC. Understanding carbon lock-in. Energy Policy 2000;28:817-30.

[75] Aldrich HE, Fiol CM. Fools rush in? The institutional context of industry creation. The Academy of Management Review 1994;19:645-70.

[76] Walz R. The role of regulation for sustainable infrastructure innovations: the case of wind energy. International Journal Public Policy 2007;2:57-68.

[77] Meijer ISM, Hekkert MP, Koppenjan JFM. The influence of perceived uncertainty on entrepreneurial action in emerging renewable energy technology; biomass gasification projects in the Netherlands. Energy Policy 2007;35: 5836-54.

[78] Meijer ISM, Koppenjan JFM, Pruyt E, Negro SO, Hekkert MP. The influence of perceived uncertainty on entrepreneurial action in the transition to a low-emission energy infrastructure: the case of biomass combustion in the Netherlands. Technological Forecasting and Social Change 2010;77:1222-36.

[79] Raven RPJM, Geels FW. Socio-cognitive evolution in niche development: comparative analysis of biogas development in Denmark and the Netherlands (1973-2004). Technovation 2010;30:87-99.

[80] Markard J, Truffer B. Actor oriented analysis of innovation systems: findings from a case study on stationary fuel cells; 2006

[81] Bakker S. The car industry and the blow-out of the hydrogen hype. Energy Policy 2010;38:6540-4.

[82] Suurs RAA, Hekkert MP, Smits REHM. Understanding the build-up of a technological innovation system around hydrogen and fuel cell technologies; 2009.

[83] Sinke W. A Strategic research agenda for photovoltaic solar energy technology research and development in support of realizing the vision for photovoltaic technology; 2007

[84] Sinke W, Swens J, Janson B, Witte F. Analyse 13 Zon PV, Analyse Transitie Paden; 2008.

[85] Bergek A. Shaping and exploiting technological opportunities: the case of renewable energy technology in Sweden; 2002.

[86] Dumont M, Reinders J, Negro SO. Analyse Groen Gas transitiepad; 2008

[87] Smink MM, Hekkert MP, Negro SO. Keeping sustainable innovation on a leash. Exploring incumbents' strategies with regard to disruptive innovation in the Netherlands energy field through 2000-2010. Paper presented at the 2nd international conference on sustainability transitions; diversity, plurality and change: breaking new grounds in sustainability transition research; 2011.

[88] Hellsmark H, Jacobsson S. Opportunities for and limits to academics as system builders - the case of realizing the potential of gasified biomass in Austria. Energy Policy 2009;37:5597-611. 